\title{
IMPLEMENTASI KOOPERATIF NHT MENINGKATKAN AKTIVITAS DAN HASIL BELAJAR ATLETIK LOMPAT JAUH GAYA JONGKOK
}

\author{
I Kadek Arsa Jaya1,* \\ 1 Universitas Pendidikan Ganesha
}

\begin{abstract}
Abstrak
Penelitian ini bertujuan meningkatkan aktivitas dan hasil belajar lompat jauh gaya jngkok melalui implementasi model pembelajaran kooperatif tipe NHT pada Peserta didik kelas X Boga A3 SMK Negeri 2 Sigaraja tahun pelajaran 2017/2018.

Penelitian ini adalah penelitian tindakan kelas (guru sebagai peneliti) dilaksanakan dalam dua siklus, terdiri dari rencana tindakan, pelaksanaan tindakan, observasi atau evaluasi dan refleksi. Subjek penelitian adalah peserta didik kelas X Boga A3 SMK Negeri 2 Sigaraja tahun pelajaran 2017/2018, berjumlah 36 orang dengan 21 orang putra dan 15 orang putri. Data dianalisis menggunakan analisis statistik deskriptif. Berdasarkan hasil analisis data didapatkan rata-rata aktivitas belajar lompat jauh gaya jongkok secara klasikal pada observasi awal 6,19 (cukup aktif), pada siklus I meningkat menjadi 6,92 (cukup aktif), dan 7,22 (aktif) pada siklus II. Sedangkan persentase ketuntasan hasil belajar kompetensi pengetahuan dari observasi awal sebesar 5,56\% (tuntas), pada siklus I menjadi 75 \% (tuntas) dan 94,44\% (tuntas) pada siklus II. Peningkatan hasil belajar secara signifikan juga terjadi pada kompetensi sikap dan kompetensi keterampilan.

Berdasarkan hasil analisis data dan pembahasan disimpulkan bahwa aktivitas dan hasil belajar lompat jauh gaya jongkok meningkat melalui implementasi model pembelajaran kooperatif tipe NHT pada peserta didik kelas X Boga A3 SMK Negeri 2 Sigaraja tahun pelajaran 2017/2018. Disarankan kepada guru PJOK agar menggunakan model pembelajaran kooperatif tipe NHT karena dapat meningkatkan aktivitas dan hasil belajar lompat jauh peserta didik.
\end{abstract}

Kata Kunci:

Kooperatif, NHT

\section{PENDAHULUAN}

Pendidikan memegang peranan yang sangat penting untuk menjamin kelangsungan hidup bangsa dan negara, karena pendidikan merupakan wahana untuk meningkatkan dan mengembangkan kualitas sumber daya manusia. Pendidikan yang mampu mendukung pembangunan di masa mendatang adalah pendidikan yang mampu mengembangkan peserta didik, sehingga yang bersangkutan mampu menghadapi dan memecahkan problema kehidupan yang dihadapinya. Proses pembelajaran guru bukanlah hanya berperan sebagai model atau teladan bagi peserta didik yang diajarnya, tetapi juga sebagai pengelola pembelajaran. Dengan demikian efektivitas proses pembelajaran terletak di pundak guru. Keberhasilan suatu proses pembelajaran sangat di tentukan oleh kualitas atau kemampuan guru, selain itu juga dari segi model-model pembelajaran yang harus direncanakan sesuai dengan situasi dan kondisi peserta didik saat ini. Oleh karenanya, guru harus memahami karakteristik materi, perserta didik, dan metodologi pembelajaran dalam proses pembelajaran terutama berkaitan dengan pemilihan modelmodel pembelajaran. Dengan demikian, proses pembelajaran akan lebih variatif, inovatif, dan konstruktif sehingga dapat meningkatkan aktivitas dan kreativitas peserta didik (Trianto, 2009: 8-9).

Berdasarkan hasil observasi awal yang dilakukan peneliti pada hari senin, senin 7 september 2017 di kelas X BOGA A3 SMK Negeri 2 Singaraja tahun pelajaran 2017/2018, aktivitas belajar 36 peserta didik (15 peserta didik perempuan dan 21 peserta didik laki-laki) pada materi teknik lompat jauh gaya jongkok yang diperoleh pada saat observasi tergolong cukup aktif. Dapat dilihat dari komponen aktivitas belajar peserta didik yang terdiri dari kegiatan visual, lisan, mendengarkan, metrik, mental dan emosional. 
Berdasarkan hasil pengamatan dari keenam komponen aktivitas tersebut didapatkan hasil persentase sebagai berikut:

Peserta didik pada kategori sangat aktif tidak ada (0\%), 9 orang $(25,00 \%)$ berada dalam kategori tingkat aktivitas yang aktif, 24 orang $(66,67 \%)$ berada dalam kategori tingkat aktivitas yang cukup aktif, 3 orang $(8,33 \%)$ berada dalam kategori tingkat aktivitas yang kurang aktif, dan tidak ada orang $(0 \%)$ berada dalam kategori tingkat aktivitas yang sangat kurang aktif, dengan persentase ketuntasan 14 orang $(25.00 \%)$ tuntas dan 25 orang $(75.00 \%)$ tidak tuntas. Berdasarkan data di atas, maka peneliti bisa mengetahui rata-rata klasikal aktivitas belajar teknik lompat jauh gaya jongkok sebesar 6,19 yang tergolong dalam kategori cukup aktif. Sehingga dapat diketahui berapa banyak peserta didik yang tuntas dan peserta didik tidak tuntas .

Jika dilihat dari hasil observasi, ketuntasan hasil belajar untuk aspek pengetahuan, peserta didik yang berada pada kategori baik 2 orang (5,55 \%), dan pada kategori cukup baik 34 orang $(94,45 \%)$. Jadi jumlah siswa yang tuntas dalam lompat jauh gaya jongkok aspek pengetahuan secara klasikal yaitu 2 orang $(5,55 \%)$ tuntas dan 34 orang $(94,45 \%)$ tidak tuntas, dengan presentase nilai rata-rata hasil belajar secara klasikal yaitu 70,61 yang berada pada kategori tidak tuntas. Dengan menganalisa data hasil belajar kompetensi pengetahuan peserta didik secara keseluruhan terlihat hasil belajar kompetensi pengetahuan belum memenuhi sasaran, karena belum memenuhi standar kriteria ketuntasan minimal (KKM) sekolah untuk mata pelajaran PJOK sebesar 78. Permasalahan yang muncul pada aspek pengetahuan adalah kurangnya pemahaman peserta didik mengenai mengenai materi lompat jauh gaya jongkok, hal ini disebebkan oleh kurangnya penjelasan guru saat pembelajaran.

Ketuntasan hasil belajar untuk aspek keterampilan, peserta didik yang berada pada kategori baik sebanyak 5 orang $(13,89 \%)$, cukup baik sebanyak 31 orang $(86,11 \%)$. Jadi jumlah siswa yang tuntas dalam lompat jauh gaya jongkok aspek keterapilan secara klasikal yaitu 5 orang $(13,89 \%)$ tuntas dan 31 orang $(86,11 \%)$ tidak tuntas, dengan presentase nilai rata-rata hasil belajar secara klasikal yaitu $86,11 \%$ yang berada pada kategori tidak tuntas. Dengan menganalisa data hasil belajar kompetensi keterampilan peserta didik secara keseluruhan terlihat hasil belajar kompetensi keterampilan belum memenuhi target, karena belum memenuhi standar KKM sekolah untuk mata pelajaran PJOK sebesar 78 \%. Pada aspek keterampilan permasalahan yang terjadi adalah masih banyak peserta didik yang salah dalam melakukan gerakan lompat jauh gaya jongkok yaitu: (1) dari tahap tolakan masih banyak peserta didik ragu-ragu menginjak papan tumpu, (2) pada tahap melayang peserta didik tidak menggunakan gaya jongkok.

Sedangkan ketuntasan hasil belajar untuk aspek sikap, peserta didik yang berada pada kategori baik 4 orang $(11,11 \%)$ dan cukup baik 32 orang $(88,89 \%)$. Jadi jumlah siswa yang tuntas dalam lompat jauh gaya jongkok aspek sikap secara klasikal yaitu 4 orang $(11,11 \%)$ tuntas dan 31 orang $(88,89 \%)$ tidak tuntas, dengan presentase nilai rata-rata hasil belajar secara klasikal yaitu $88,89 \%$ yang berada pada kategori tidak tuntas. Dengan menganalisa data hasil belajar kompetensi sikap peserta didik secara keseluruhan terlihat hasil belajar kompetensi sikap sudah memenuhi ketuntasan, karena sudah memenuhi standar KKM sekolah untuk mata pelajaran PJOK sebesar 78. Adanya peserta didik yang bermasalah pada apek hasil belajar peserta didik disebabkan oleh (1) dari segi kerjasama, peserta didik masih kurang untuk melakukan kerjasama didalam pembelejaran dan cenderung individual, (2) dari segi disiplin, peserta didik masih banyak yang berpakaian kurang rapi, terlambat saat datang dan melakukan kegiatan diluar materi saat pembelajaran, (3) dari segi tanggung jawab, peserta didik kurang bertanggung jawab didalam pemakain sarana pembelajaran berupa kardus bekas yang sebagai media pembelajaran.

Jadi jika dilihat dari rata-rata aktivitas dan hasil belajar lompat jauh gaya jongkok di atas dapat disimpulkan bahwa, aktivitas dan hasil belajar lompat jauh gaya jongkok kelas X Boga A3 SMK Negri 2 Singaraja tidak tuntas. Hal ini disebabkan implementasi model pembelajaran yang belum efektif terhadap materi yang disajikan. Model pembelajaran yang diimplementasikan belum melibatkan atau merangsang peserta didik untuk lebih aktif dan kreatif selama proses pembelajaran berlangsung. Berdasarkan permasalahan di atas, peneliti mencoba memberikan salah satu alternatif pemecahan masalah yaitu dengan menerapkan model pembelajaran kooperatif tipe NHT (Numbered Head Together) dalam pembelajaran PJOK pada materi lompat jauh gaya jongkok. Ketertarikan peneliti menerapkan model pembelajaran kooperatif tipe NHT ini karena (1) model pembelajaran kooperatif dengan tipe NHT adalah model pembelajaran yang sederhana, sehingga model pembelajaran kooperatif ini cocok diterapkan pada peserta didik kelas X Boga A3 SMK Negeri 2 Singaraja yang belum pernah melakukan pembelajaran kooperatif tipe NHT, (2) pada model pembelajaran ini peserta didik lebih banyak mempunyai kesempatan diskusi kelompok, masing-masing peserta didik memberikan partisipasinya secara maksimal dan setiap peserta didik mempunyai tanggung jawab perseorangan untuk menguasai materi dengan sebaik-baiknya, (3) model pembelajaran kooperatif dengan tipe NHT mengajak peserta didik untuk belajar aktif dan berani dalam mengeluarkan pendapat dalam diskusi kelompok. Apabila ada suatu konsep yang belum dimengerti dan dipahaminya, peserta didik dapat saling isi mengisi dengan peserta didik lain, saling 
bertukar pikiran sehingga diharapkan konsep yang dimiliki peserta didik benar-benar dapat dipahami dengan baik. Suasana belajar akan lebih kondusif, yang akhirnya berpengaruh terhadap aktivitas dan hasil belajar.

NHT atau penomoran berpikir bersama adalah merupakan jenis pembelajaran kooperatif yang dirancang untuk mempengaruhi pola interaksi peserta didik dan sebagai alternatif terhadap struktur kelas tradisional (Trianto, 2007:62). NHT pertama kali dikembangkan oleh Spenser Kagan (1993) untuk melibatkan lebih banyak peserta didik dalam menelaah materi yang tercakup dalam suatu pelajaran dan mengecek pemahaman mereka terhadap isi pelajaran tersebut.

Pemilihan tentang model pembelajaran NHT ini juga dikuatkan oleh hasil penelitian dari penelitipeneliti sebelumnya diantaranya (1) Penelitian yang dilakukan oleh Sanjaya, I.P.E.Y (2013 :123) dalam skripsinya yang menyimpulkan motivasi dan hasil belajar teknik Lompat jauh gaya jongkok meningkat melalui penerapan model pembelajaran kooperatif tipe NHT pada peserta didik kelas X.5 SMA Negeri 1 Negara tahun pelajaran 2012/2013, (2) Penelitian yang dilakukan oleh Bawa, I.M.L (2012:116) dalam skripsinya yang menyimpulkan aktivitas dan hasil belajar teknik dasar passing sepak bola meningkat melalui penerapan model pembelajaran kooperatif tipe NHT pada peserta didik kelas X.1 SMK Negeri 2 Singaraja tahun pelajaran 2011/2012, (3) Penelitian yang dilakukan oleh Tirtawati, N.W (2013 :103) dalam skripsinya yang menyimpulkan motivasi dan hasil belajar lompat jauh gaya jongkok meningkat melalui penerapan model pembelajaran kooperatif tipe NHT pada peserta didik kelas XI IPA 3 SMA Negeri 2 Bangli tahun pelajaran 2012/2013.

Berdasarkan uraian di atas, maka peneliti bermaksud mengadakan penelitian dengan judul "Implementasi model pembelajaran kooperatif tipe Numbered Head Together (NHT) untuk meningkatkan aktivitas dan hasil belajar lompat jauh gaya jongkok pada peserta didik kelas X Boga A3 SMK Negeri 2 Singaraja tahun pelajaran 2017/2018".

\section{METODE PENELITIAN}

Jenis penelitian yang digunakan adalah penelitian tindakan kelas. Menurut Arikunto dkk, (2008: 2-3) dikarenakan ada tiga kata yang membentuk pengertian tersebut, maka ada tiga pengertian yang dapat diterangkan sebagai berikut a) Penelitian, menunjuk pada suatu kegiatan mencermati suatu objek dengan menggunakan cara dan aturan metodologi tertentu untuk memproleh data atau informasi yang bermaanfat dalam meningkatkan mutu suatu hal yang menarik minat dan penting bagi peneliti, b) Tindakan, menunjuk pada sesuatu gerak kegiatan yang disengaja dilakukan dengan tujuan tertentu, c) Kelas, dalam hal ini tidak terikat pada pengertian ruang kelas, tetapi dalam pengertian yang lebih spesifik.

Dengan menggabungkan batasan pengertian tiga kata inti, yaitu (1) penelitian, (2) tindakan, (3) kelas, dapat disimpulkan bahwa penelitian tindakan kelas merupakan suatu pencermatan terhadap kegiatan belajar berupa sebuah tindakan, yang sengaja dimunculkan dan terjadi dalam sebuah kelas secara bersama.

Oja dan Smulyan membedakan adanya empat bentuk penelitian tindakan, yaitu (1) guru sebagai peneliti, (2) penelitian Tindakan Kolaboratif, (3) simultan-Terintregasi, (4) administrasi Sosial Eksperimental (Kanca, I Nyoman, 2010: 115). Dalam penelitian ini bentuk penelitian tindakan yang digunakan adalah guru sebagai peneliti. Karena peneliti sudah menjadi guru, maka dalam penelitian ini menggunakan bentuk penelitan peneliti sebagai guru, karena dalam bentuk PTK yang memandang guru sebagai peneliti mempunyai ciri-ciri penting yaitu sangat berperannya guru itu sendiri dalam proses PTK. Tujuan utama PTK adalah untuk memperbaiki dan meningkatkan mutu profesional guru didalam proses pembelajaran.

\section{HASIL DAN PEMBAHASAN}

Penelitian ini dilaksanakan dari hari Selasa tanggal senin, 18 september 2017 sampai dengan hari Kamis tanggal 5 Oktober 2017, yang dilaksanakan setiap pukul 05.30-07.00 wita, bertempat di lapangan Bhuana Patra, dengan subjek penelitiannya adalah peserta didik kelas X Boga A3 SMK Negeri 2 Singaraja Tahun Pelajaran 2017/2018 yang berjumlah 39 orang yang terdiri dari 21 orang peserta didik putra dan 15 orang peserta didik putri. Penelitian ini dilaksanakan sebanyak dua siklus, disetiap siklus terdapat dua kali pertemuan. Siklus I pertemuan pertama dilaksanakan pada hari Selasa tanggal 18 september 2017 untuk pengambilan data aktivitas belajar peserta didik dan pertemuan kedua dilaksanakan pada hari Kamis tanggal 21 september 2017 untuk pengambilan data aktivitas dan hasil belajar peserta didik. Sedangkan siklus II pertemuan pertama dilaksanakan pada hari Selasa tanggal 2 Oktober 2017 untuk pengambilan data aktivitas belajar peserta didik dan pertemuan kedua dilaksanakan pada hari Kamis 
tanggal 5 Oktober 2017 untuk pengambilan data aktivitas dan hasil belajar peserta didik, yang bertempat di lapangan Bhuana Patra, untuk pengambilan data aktivitas dan hasil belajar peserta didik melibatkan 2 orang guru PJOK SMK Negeri 2 Singaraja bertindak sebagai observer dan sekaligus menjadi evaluator.

Tabel 1.

Hasil Analisis Data Aktivitas Belajar Lompat jauh gaya jongkok pada Siklus I

\begin{tabular}{|c|c|c|c|c|c|}
\hline No & Kriteria & $\begin{array}{c}\text { Jumlah } \\
\text { Peserta } \\
\text { Didik } \\
\end{array}$ & Persentase & Kategori & Keterangan \\
\hline 1 & $X \geq 9$ & 4 & $11,1 \%$ & Sangat Aktif & \multirow{2}{*}{$\begin{array}{c}23 \text { Orang Peserta } \\
\text { Didik aktif } \\
(63,89 \%)\end{array}$} \\
\hline 2 & $7 \leq \bar{X}<9$ & 19 & $52,78 \%$ & Aktif & \\
\hline 3 & $5 \leq \bar{X}<7$ & 13 & $36.11 \%$ & Cukup Aktif & \multirow{3}{*}{$\begin{array}{c}13 \text { Orang Peserta } \\
\text { Didik Tidak Aktif } \\
(36.11 \%)\end{array}$} \\
\hline 4 & $3 \leq \bar{X}<5$ & 0 & - & Kurang Aktif & \\
\hline 5 & $\bar{X}<3$ & - & - & Sangat Kurang Aktif & \\
\hline & & 36 & $100 \%$ & - & $\begin{array}{c}36 \text { Peserta Didik } \\
(100 \%)\end{array}$ \\
\hline
\end{tabular}

Dari tabel 1 di atas dapat dilihat bahwa, peserta didik yang berada pada kategori sangat aktif 4 orang (11,1\%), kategori aktif 19 orang (52.78\%), kategori cukup aktif 13 orang (36.11\%), dalam kategori kurang aktif $0(0 \%)$, dan tidak ada peserta didik yang berada sangat kurang aktif. Dari hasil analisis data diatas maka dapat dikatakan bahwa implementasi model pembelajaran NHT cukup efektif untuk meningkatkan aktivitas belajar lompat jauh gaya jongkok, hal ini dapat dilihat dari persentase ketuntasan belajar yang mencapai $63.89 \%$ (23 orang).

Tabel 2.

Data Hasil Belajar Aspek Pengetahuan Teknik Lompat Jauh Gaya Jongkok Siklus 1

\begin{tabular}{cccccc}
\hline No & Rentang Skor & Predikat & $\begin{array}{c}\text { Jumlah Peserta } \\
\text { Didik }\end{array}$ & Persentase & $\begin{array}{c}\text { Jumlah Ketunasan } \\
\text { Peserta Didik }\end{array}$ \\
\hline $\mathbf{1}$ & $92-100$ & Sangat Baik & 6 Peserta Didik & $16,67 \%$ & 27Peserta Didik \\
$\mathbf{2}$ & $78-91$ & Baik & 21 Peserta Didik & $58,33 \%$ & $75,00 \%$ Tuntas \\
$\mathbf{3}$ & $63-77$ & Cukup Baik & 9 Peserta Didik & $25,00 \%$ & 9 Peserta Didik \\
$\mathbf{4}$ & $\leq 62$ & Kurang Baik & 0 Peserta Didik & $0,00 \%$ & 25,00\%Tidak Tuntas \\
& Jumlah & & $\mathbf{3 6}$ & $\mathbf{1 0 0 \%}$ & \\
\hline
\end{tabular}

Berdasarkan Tabel 2 hasil belajar aspek pengetahuan pada siklus I dengan materi lompat jauh gaya jongkok, diperoleh data hasil belajar dengan kategori individu sebagai berikut, 6 orang kategori sangat baik (16.67\%), 21 orang peserta didik (53.33\%) memperoleh nilai dengan kategori baik, 9 orang peserta didik $(25,00 \%)$ memperoleh nlai dengan kategori cukup, dan tidak ada peserta didik yang memperoleh nilai dengan kategori kurang.

Tabel 3.

Hasil Analisis Data Hasil Belajar Aspek Sikap Lompat Jauh Gaya Jongkok pada Siklus I

\begin{tabular}{|c|c|c|c|c|c|}
\hline No & Rentang Skor & Predikat & $\begin{array}{c}\text { Jumlah } \\
\text { Peserta Didik }\end{array}$ & Persentase & $\begin{array}{c}\text { Jumlah } \\
\text { Ketunasan } \\
\text { Peserta Didik } \\
\end{array}$ \\
\hline 1 & $92-100$ & $\begin{array}{l}\text { Sangat } \\
\text { Baik }\end{array}$ & 4 Peserta Didik & $11,11 \%$ & 18 Peserta Didik \\
\hline 2 & $78-91$ & Baik & $\begin{array}{l}14 \text { Peserta } \\
\text { Didik }\end{array}$ & $38,89 \%$ & $50,00 \%$ Tuntas \\
\hline 3 & $63-77$ & Cukup & 18 Peserta & $5000 \%$ & 1 Peserta Didik \\
\hline 4 & $\leq 62$ & Kurang & 0 Peserta Didik & $0,00 \%$ & Tuntas \\
\hline
\end{tabular}




\begin{tabular}{llll}
\hline Jumlah & Baik & 36 & $100 \%$ \\
\hline
\end{tabular}

Berdasarkan Tabei 3 di atas, hasil belajar aspek sikap pada siklus I dengan materi lompat jauh gaya jongkok, diperoleh data hasil belajar dengan kategori individu sebagai berikut, peserta didik dengan kategori sangat baik 4 orang (11.11\%), 14 orang peserta didik $(38,89 \%)$ memperoleh nilai dengan kategori baik, 18 orang peserta didik (50.00\%) dengan kategori cukup, dan tidak ada peserta didik yang memperoleh nilai dengan kategori kurang.

Tabel 4.

Hasil Analisis Data Hasil Belajar Aspek Keterampilan Lompat Jauh Gaya Jongkok pada Siklus I

\begin{tabular}{|c|c|c|c|c|c|}
\hline No & Rentang Skor & Predikat & $\begin{array}{c}\text { Jumlah } \\
\text { Peserta } \\
\text { Didik } \\
\end{array}$ & Persentase & $\begin{array}{c}\text { Jumlah Ketunasan Peserta } \\
\text { Didik }\end{array}$ \\
\hline 1 & $92-100$ & Sangat Baik & $\begin{array}{l}4 \text { Peserta } \\
\text { Didik }\end{array}$ & $11,11 \%$ & 22 Peserta Didik \\
\hline 2 & $78-91$ & Baik & $\begin{array}{l}18 \text { Peserta } \\
\text { Didik }\end{array}$ & $50,00 \%$ & $61,11 \%$ Tuntas \\
\hline 3 & $63-77$ & Cukup Baik & $\begin{array}{l}14 \text { Peserta } \\
\text { Didik }\end{array}$ & $38,5 \%$ & 14 Peserta Didik \\
\hline 4 & $\begin{array}{l}\leq 62 \\
\text { Jumlah }\end{array}$ & Kurang Baik & $\begin{array}{c}0 \text { Peserta } \\
\text { Didik } \\
\mathbf{3 6}\end{array}$ & $\begin{array}{l}0,00 \% \\
\mathbf{1 0 0} \%\end{array}$ & $38,89 \%$ Tidak Tuntas \\
\hline
\end{tabular}

Berdasarkan tabel 4. hasil belajar aspek keterampilan pada siklus I dengan materi lompat jauh gaya jongkok, diperoleh data hasil belajar dengan kategori individu sebagai berikut, 4 orang kategori sangat baik (11.11\%), 18 orang (50.00\%) memperoleh nilai dengan kategori baik, 14 orang $(38,89 \%)$ memperoleh nilai dengan kategori cukup, dan tidak ada peserta didik yang memperoleh nilai dengan kategori kurang.

Tabel 5.

Hasil Analisis Data Aktivitas Belajar Lompat Jauh Gaya Jongkok pada Siklus II

\begin{tabular}{|c|c|c|c|c|c|}
\hline No & Kriteria & $\begin{array}{c}\text { Jumlah } \\
\text { Peserta } \\
\text { Didik }\end{array}$ & Persentase & Kategori & Keterangan \\
\hline 1 & $\bar{X} \geq 9$ & 9 & $25,00 \%$ & Sangat Aktif & \multirow{2}{*}{$\begin{array}{c}31 \text { Orang Peserta } \\
\text { Didik aktif } \\
(86,11 \%)\end{array}$} \\
\hline 2 & $7 \leq \bar{X}<9$ & 22 & $61,11 \%$ & Aktif & \\
\hline 3 & $5 \leq \bar{X}_{<7}$ & 5 & $13,89 \%$ & Cukup Aktif & \multirow{3}{*}{$\begin{array}{c}5 \text { Orang Peserta } \\
\text { Didik Tidak Aktif } \\
(13,89 \%)\end{array}$} \\
\hline 4 & $3 \leq \bar{X}_{<5}$ & 0 & - & Kurang Aktif & \\
\hline 5 & $\bar{X}<3$ & - & - & Sangat Kurang Aktif & \\
\hline & Total & 36 & $100 \%$ & - & $\begin{array}{c}36 \text { Peserta Didik } \\
(100 \%)\end{array}$ \\
\hline
\end{tabular}

Dari Tabel 5. di atas dapat dilihat bahwa, peserta didik yang berada pada kategori sangat aktif 9 orang (25,00\%), kategori aktif 22 orang (61.11\%), kategori cukup aktif 5 orang (13,89\%), dan tidak ada peserta didik yang berada dalam kategori kurang aktif, dan sangat kurang aktif. 
Tabel 6.

Hasil Analisis Data Hasil Belajar Aspek Pengetahuan Lompat Jauh Gaya Jongkok pada Siklus II

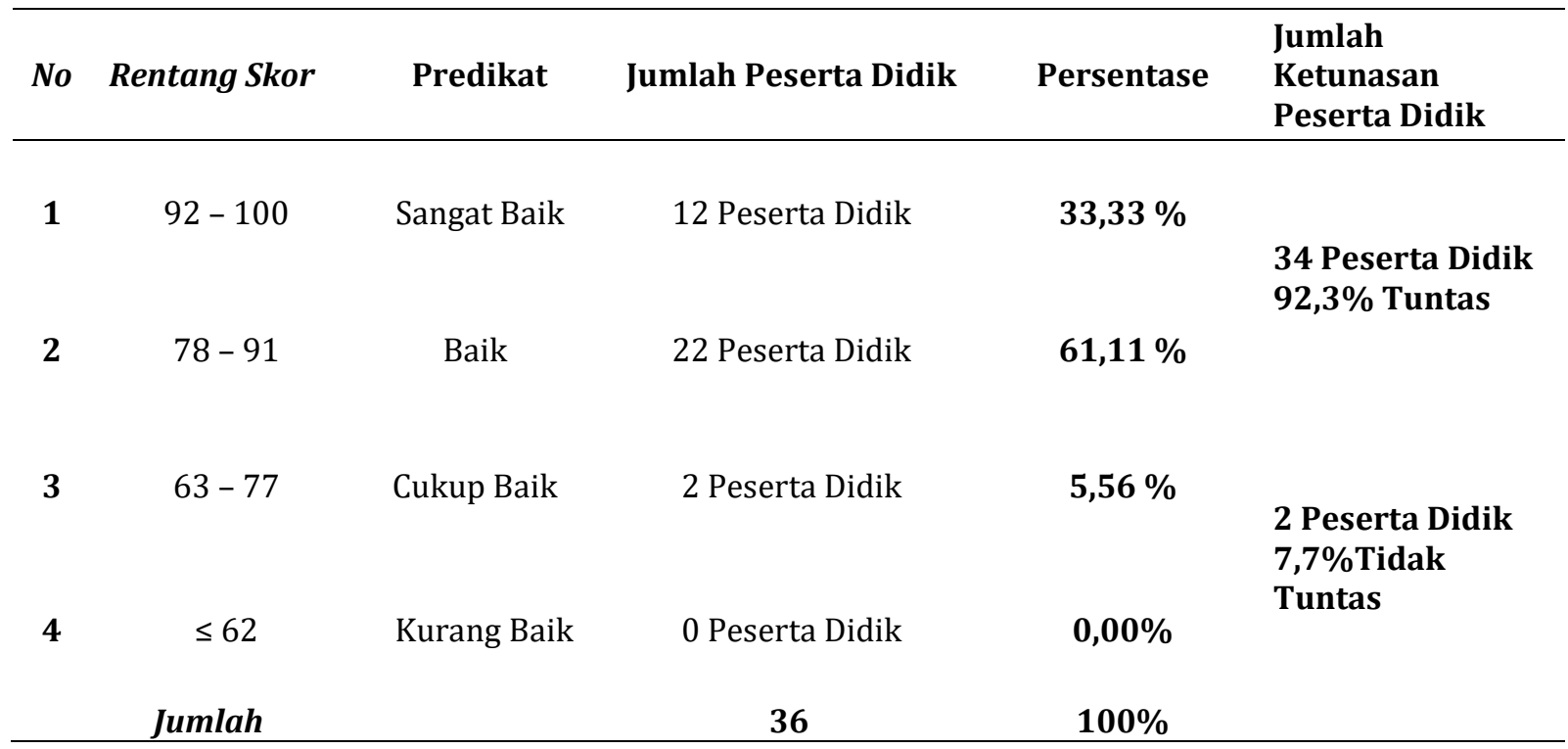

Berdasarkan tabel 6, hasil belajar aspek pengetahuan pada siklus II dengan materi lompat jauh gaya jongkok, diperoleh data hasil belajar dengan kategori individu sebagai berikut, 12 kategori sangat baik (33.33\%), 22 orang peserta didik (61,11\%) memperoleh nilai dengan kategori baik, 2 orang peserta didik (5.56 \%) memperoleh nilai dengan kategori cukup, dan tidak ada peserta didik yang memperoleh nilai dengan kategori kurang.

Tabel 7.

Hasil Analisis Data Hasil Belajar Aspek Sikap Lompat Jauh Gya Jngkok pada Siklus II

\begin{tabular}{|c|c|c|c|c|c|}
\hline No & Rentang Skor & Predikat & $\begin{array}{c}\text { Jumlah } \\
\text { Peserta } \\
\text { Didik }\end{array}$ & Persentase & $\begin{array}{l}\text { Jumlah Ketunasan } \\
\text { Peserta Didik }\end{array}$ \\
\hline 1. & $92-100$ & Sangat Baik & $\begin{array}{l}9 \text { Peserta } \\
\text { Didik }\end{array}$ & $25,00 \%$ & 32 Peserta Didik \\
\hline 2. & $78-91$ & Baik & $\begin{array}{l}23 \text { Peserta } \\
\text { Didik }\end{array}$ & $63,89 \%$ & $88,89 \%$ Tuntas \\
\hline 3. & $63-77$ & Cukup Baik & $\begin{array}{l}4 \text { Peserta } \\
\text { Didik }\end{array}$ & $11,11 \%$ & 4 Peserta Didik \\
\hline \multirow[t]{2}{*}{4.} & $\leq 62$ & Kurang Baik & $\begin{array}{l}0 \text { Peserta } \\
\text { Didik }\end{array}$ & $0,00 \%$ & $11,11 \%$ Tidak Tuntas \\
\hline & Jumlah & & 36 & $100 \%$ & \\
\hline
\end{tabular}

Berdasarkan tabei 7. hasil belajar aspek sikap pada siklus II dengan materi lompat jauh gaya jongkok, diperoleh data hasil belajar dengan kategori individu sebagai berikut 9 orang (25,00\%) dengan kategori sangat baik, 23 orang peserta didik (63.89\%) memperoleh nilai dengan kategori baik, 4 orang peserta didik (11.11\%) memperoleh nilai dengan kategori cukup dan tidak ada peserta didik yang memperoleh nilai dengan kategori kurang. 
Tabel 8.

Hasil Analisis Data Hasil Belajar Aspek Keterampilan Lompat Jauh Gaya Jongkok pada Siklus II

\begin{tabular}{|c|c|c|c|c|c|}
\hline No & Rentang Skor & Predikat & $\begin{array}{c}\text { Jumlah Peserta } \\
\text { Didik }\end{array}$ & Persentase & $\begin{array}{c}\text { Jumlah Ketunasan } \\
\text { Peserta Didik }\end{array}$ \\
\hline 1. & $92-100$ & Sangat Baik & 9 Peserta Didik & $25,00 \%$ & 34 Peserta Didik \\
\hline 2. & $78-91$ & Baik & 23 Peserta Didik & $63,89 \%$ & $88,89 \%$ Tuntas \\
\hline 3. & $63-77$ & Cukup Baik & 4 Peserta Didik & $11,11 \%$ & 4 Peserta Didik \\
\hline 4. & & $\begin{array}{c}\text { Kurang } \\
\text { Baik }\end{array}$ & 0 Peserta Didik & $0,00 \%$ & $11,11 \%$ Tidak Tuntas \\
\hline & Jumlah & & 36 & $100 \%$ & \\
\hline
\end{tabular}

Berdasarkan Tabel 8. hasil belajar aspek keterampilan pada siklus II dengan materi lompat jauh gaya jongkok, diperoleh data hasil belajar dengan kategori individu sebagai berikut, 9 kategori sangat baik (25,.00\%), 23 orang (63.89\%) memperoleh nilai dengan kategori baik, 4 orang (11.11\%) memperoleh nilai dengan kategori cukup, dan tidak ada peserta didik yang memperoleh nilai dengan kategori kurang.

Tabel 9

Ringkasan Data Aktivitas Belajar Peserta didik dari Observasi Awal, Siklus I, dan Siklus II

\begin{tabular}{|c|c|c|c|c|c|c|}
\hline \multirow[b]{2}{*}{ No } & \multirow[b]{2}{*}{ Tahapan } & \multirow[b]{2}{*}{$\begin{array}{c}\text { Aktivitas } \\
\text { Belajar } \\
\text { Klasikal }\end{array}$} & \multirow{2}{*}{$\begin{array}{c}\text { Keaktifan } \\
\text { Peserta } \\
\text { didik } \\
\text { (Orang) } \\
\end{array}$} & \multicolumn{3}{|c|}{ Peningkatan Aktivitas Belajar } \\
\hline & & & & $\begin{array}{c}\text { Observasi } \\
\text { Awal ke } \\
\text { Siklus I } \\
\end{array}$ & $\begin{array}{c}\text { Siklus I ke } \\
\text { Siklus II }\end{array}$ & $\begin{array}{c}\text { Observasi } \\
\text { Awal ke } \\
\text { Siklus II } \\
\end{array}$ \\
\hline 1. & $\begin{array}{c}\text { Observasi } \\
\text { Awal }\end{array}$ & 6,19 & $\begin{array}{l}9(25.00 \%) \\
\text { Sudah Aktif }\end{array}$ & $\begin{array}{l}14 \text { Orang } \\
(38.89 \%)\end{array}$ & & \\
\hline 2. & Siklus I & 6,92 & $\begin{array}{c}23(63.89 \%) \\
\text { Sudah Aktif }\end{array}$ & & $\begin{array}{l}8 \text { Orang } \\
(22.22 \%)\end{array}$ & $\begin{array}{l}22 \text { Orang } \\
(61.11 \%)\end{array}$ \\
\hline 3. & Siklus II & 7,22 & $\begin{array}{c}31(86,11 \%) \\
\text { Sudah Aktif }\end{array}$ & & & \\
\hline
\end{tabular}

Berdasarkan Tabel 9, data aktivitas belajar atletik lompat jauh gaya jongkok pada peserta didik kelas X Boga A3 SMK Negeri 2 Singaraja dapat disampaikan bahwa, peserta didik yang sudah aktif pada observasi awal 9 orang $(25.00 \%)$. Kemudian setelah diberikan tindakan pada siklus I peserta didik yang aktif menjadi 23 orang (63.89\%) dengan peningkatan 14 orang (38.89\%) dari observasi awal. Karena pada siklus I aktivitas peserta didik masih perlu ditingkatkan, sehingga pada siklus II kembali diberikan tindakan. Setelah diberikan tindakan pada siklus II, aktivitas peserta didik meningkat 8 orang (22.22\%) dari siklus I dan pada siklus II 31 orang (63.89\%) sudah berada dalam kategori aktif ,dan dari observasi awal ke siklus II terjadi peningkatan 22 orang (61.11\%). 
Tabel 10.

Ringkasan Data Hasil Belajar Aspek Pengetahuan Peserta didik dari Observasi Awal, Siklus I, dan Siklus II

\begin{tabular}{|c|c|c|c|c|c|c|}
\hline \multirow[b]{2}{*}{ No } & \multirow[b]{2}{*}{ Tahapan } & \multirow{2}{*}{$\begin{array}{c}\text { Persentase } \\
\text { Ketuntasan } \\
\text { Hasil } \\
\text { Belajar } \\
\end{array}$} & \multirow[b]{2}{*}{$\begin{array}{c}\text { Ketuntasan } \\
\text { Peserta } \\
\text { didik }\end{array}$} & \multicolumn{3}{|c|}{ Peningkatan Hasil Belajar } \\
\hline & & & & $\begin{array}{c}\text { Observasi } \\
\text { Awal ke } \\
\text { Siklus I } \\
\end{array}$ & $\begin{array}{c}\text { Siklus I ke } \\
\text { Siklus II }\end{array}$ & $\begin{array}{c}\text { Observasi } \\
\text { Awal ke } \\
\text { Siklus II } \\
\end{array}$ \\
\hline 1. & $\begin{array}{c}\text { Observasi } \\
\text { Awal }\end{array}$ & $\begin{array}{l}2 \text { Orang } \\
(5.56 \%)\end{array}$ & Tuntas & $\begin{array}{l}25 \text { Orang } \\
(69.44 \%)\end{array}$ & & \\
\hline 2. & Siklus I & $\begin{array}{l}27 \text { Orang } \\
(75.00 \%)\end{array}$ & Tuntas & & $\begin{array}{r}7 \text { Orang } \\
(19.44 \%)\end{array}$ & \\
\hline 3. & Siklus II & $\begin{array}{l}34 \text { Orang } \\
(94.44 \%)\end{array}$ & Tuntas & & & \\
\hline
\end{tabular}

Berdasarkan Tabel 10. hasil analisis data hasil belajar aspek pengetahuan lompat jauh gaya jongkokpada peserta didik kelas X Boga A3 SMK Negeri 2 Singaraja dapat disampaikan bahwa, persentase ketuntasan hasil belajar aspek pengetahuan peserta didik pada observasi awal sebesar 2 orang (5.56\%). Setelah diberikan tindakan pada siklus I hasil belajar lompat jauh gaya jongkok mengalami peningkatan sebanyak 25 orang $(69,44 \%)$ dari observasi awal, dan ketuntasan hasil belajar aspek pengetahuan pada siklus I orang $(75.00 \%)$.

Karena pada siklus I masih ada peserta didik yang belum tuntas maka diberikan tindakan pada siklus II. Setelah diberikan tindakan pada siklus II ketuntasan hasil belajar peserta didik meningkat 7 orang (19.44\%) dari siklus I, sehingga jumlah ketuntasan hasil belajar aspek pengetahuan peserta didik pada siklus II menjadi 34 orang (94.44\%). Dari hasil analisis data tersebut, dapat dilihat peningkatan ketuntasan hasil belajar aspek pengetahuan yang terjadi dari observasi awal ke siklus II 32 orang $(88.89 \%)$.

Tabel 11

Ringkasan Data Hasil Belajar Aspek Sikap Peserta didik dari Observasi Awal, Siklus I, dan Siklus II.

\begin{tabular}{|c|c|c|c|c|c|c|}
\hline \multirow[b]{2}{*}{ No } & \multirow[b]{2}{*}{ Tahapan } & \multirow{2}{*}{$\begin{array}{c}\text { Persentase } \\
\text { Ketuntasan } \\
\text { Hasil } \\
\text { Belajar }\end{array}$} & \multirow[b]{2}{*}{$\begin{array}{c}\text { Ketuntasan } \\
\text { Peserta } \\
\text { didik }\end{array}$} & \multicolumn{3}{|c|}{ Peningkatan Hasil Belajar } \\
\hline & & & & $\begin{array}{c}\text { Observasi } \\
\text { Awal ke } \\
\text { Siklus I } \\
\end{array}$ & $\begin{array}{c}\text { Siklus I ke } \\
\text { Siklus II }\end{array}$ & $\begin{array}{c}\text { Observasi } \\
\text { Awal ke } \\
\text { Siklus II } \\
\end{array}$ \\
\hline 1. & $\begin{array}{c}\text { Observasi } \\
\text { Awal }\end{array}$ & $\begin{array}{c}4 \text { Orang } \\
(11.11 \%)\end{array}$ & Tuntas & $\begin{array}{l}14 \text { Orang } \\
(38,89 \%)\end{array}$ & & \\
\hline 2. & Siklus I & $\begin{array}{l}18 \text { Orang } \\
(50.00 \%)\end{array}$ & Tuntas & & $\begin{array}{c}14 \text { Orang } \\
(38,89 \%)\end{array}$ & \\
\hline 3. & Siklus II & $\begin{array}{l}32 \text { Orang } \\
(88.89 \%)\end{array}$ & Tuntas & & & \\
\hline
\end{tabular}

Hasil analisis data hasil belajar aspek sikap lompat jauh gaya jongkok pada peserta didik kelas X Boga A3 SMK Negeri 2 Singaraja dapat disampaikan bahwa, tingkat ketuntasan hasil belajar aspek sikap peserta didik pada observasi awal 4 orang (11.11\%). Setelah diberikan tindakan pada siklus I hasil belajar aspek sikap lompat jauh gaya jongkok mengalami peningkatan 14 orang (38,89\%) dari observasi awal, dan ketuntasan hasil belajar aspek sikap pada siklus I 18 orang (50.00\%). Karena pada siklus I masih ada peserta didik yang belum tuntas maka diberikan tindakan pada siklus II. Setelah diberikan tindakan pada siklus II ketuntasan hasil belajar aspek sikap lompat jauh gaya jongkok peserta didik meningkat 14 orang 
$(38,89 \%)$ dari siklus I, sehingga jumlah ketuntasan hasil belajar aspek sikap peserta didik pada siklus II menjadi 32 orang $(88,89 \%)$. Dari hasil analisis data tersebut, dapat dilihat peningkatan ketuntasan hasil belajar aspek sikap yang terjadi dari observasi awal ke siklus II 30orang $(77,78 \%)$.

Tabel 12

Ringkasan Data Hasil Belajar Aspek Keterampilan Peserta didik dari Observasi Awal, Siklus I, dan Siklus II

\begin{tabular}{|c|c|c|c|c|c|c|}
\hline \multirow[b]{2}{*}{ No } & \multirow[b]{2}{*}{ Tahapan } & \multirow[b]{2}{*}{$\begin{array}{c}\text { Persentase } \\
\text { KetuntasanH } \\
\text { asil Belajar }\end{array}$} & \multirow[b]{2}{*}{$\begin{array}{c}\text { Ketuntasan } \\
\text { Peserta } \\
\text { didik }\end{array}$} & \multicolumn{3}{|c|}{ Peningkatan Hasil Belajar } \\
\hline & & & & $\begin{array}{c}\text { Observasi } \\
\text { Awal ke } \\
\text { Siklus I }\end{array}$ & $\begin{array}{c}\text { Siklus I ke } \\
\text { Siklus II }\end{array}$ & $\begin{array}{l}\text { Observasi } \\
\text { Awal ke } \\
\text { Siklus II }\end{array}$ \\
\hline 1. & $\begin{array}{c}\text { Observasi } \\
\text { Awal }\end{array}$ & $\begin{array}{c}5 \text { Orang } \\
(15,63 \%)\end{array}$ & Tuntas & $\begin{array}{l}17 \text { Orang } \\
(47.22 \%)\end{array}$ & & \\
\hline 2. & Siklus I & $\begin{array}{l}22 \text { Orang } \\
(61,11 \%)\end{array}$ & Tuntas & & $\begin{array}{l}12 \text { Orang } \\
(33.33 \%)\end{array}$ & $\begin{array}{l}29 \text { Orang } \\
(80.56 \%)\end{array}$ \\
\hline 3. & Siklus II & $\begin{array}{l}\text { 34 Orang } \\
(94.44 \%)\end{array}$ & Tuntas & & & \\
\hline
\end{tabular}

Berdasarkan tabel 4.11 hasil analisis data hasil belajar aspek keterampilan lompat jauh gaya jongkokpada peserta didik kelas X Boga A3 SMK Negeri 2 Singaraja dapat disampaikan bahwa, tingkat ketuntasan hasil belajar aspek keterampilan peserta didik pada observasi awal 5 orang $(15,63 \%)$. Setelah diberikan tindakan pada siklus I hasil belajar lompat jauh gaya jongkok mengalami peningkatan 17 orang (47.22\%) dari observasi awal, dan ketuntasan hasil belajar aspek keterampilan pada siklus I 22 orang $(61,11 \%)$. Karena pada siklus I masih ada peserta didik yang belum tuntas maka diberikan tindakan pada siklus II. Setelah diberikan tindakan pada siklus II ketuntasan hasil belajar peserta didik meningkat 12 orang (33.33\%) dari siklus I, sehingga jumlah ketuntasan hasil belajar aspek pengetahuan peserta didik pada siklus II menjadi 34 orang (94.44\%). Dari hasil analisis data tersebut, dapat dilihat peningkatan ketuntasan hasil belajar aspek keterampilan yang terjadi dari observasi awal ke siklus II 29 orang $(80.56 \%)$.

Berdasarkan hasil refleksi awal yang dilakukan peneliti terdapat beberapa permasalahan yang perlu diperbaiki yaitu 1) masih ditemukan pembelajaran PJOK yang yang didominasi guru, 2) proses pembelajaran masih terlihat kurang efektif dan efisien, 3) rendahnya minat belajar peserta didik terhadap mata pelajaran PJOK khususnya pada materi lompat jauh gaya jongkok, 4) gerak peserta didik kurang aktif dalam mengamati demonstrasi yang diperagakan oleh guru mengenai materi lompat jauh gaya jongkok sehingga sebagian besar peserta didik tidak dapat melakukan sikap awal, sikap pelaksanaan dan sikap akhir dengan benar, 5) kurangnya penerapan strategi belajar mengajar yang lebih banyak melibatkan peserta didik dalam proses pembelajaran, yang mengakibatkan peserta didik banyak yang diam dan kurang aktif.

Berdasarkan hasil analisis data dari implementasi model pembelajaran kooperatif tipe NHT yang bertujuan untuk meningkatkan aktivitas dan hasil belajar lompat jauh gaya jongkok, hasil penelitian aktivitas belajar peserta didik pada siklus I terhadap pembelajaran pendidikan jasmani olahraga dan kesehatan khususnya pada materi lompat jauh gaya jongkok secara klasikal berada pada kategori cukup aktif. Dengan memperhatikan aktivitas dan hasil belajar lompat jauh gaya jongkok siklus I, peneliti melanjutkan ke siklus II dengan melihat permasalahan-permasalahan pada siklus I. Hal ini terbukti dari refleksi dari siklus I yang masih terdapat permasalahan-permasalahan dalam pelaksanaan tindakan.

Adapun permasalahan-permasalahan yang dihadapi dalam pembelajaran pada siklus I yaitu: (1) peserta didik kurang mendengarkan penjelasan dari peneliti tentang lompat jauh gaya jongkok (2) peserta didik kurang memperhatikan demonstrasi yang diperagakan oleh peneliti tentang lompat jauh gaya jongkok, (3) peserta didik kurang menaruh minat dan bersemangat dalam melakukan gerakan lompat jauh gaya jongkok, (4) peserta didik belum berani mengajukan pertanyaan dan mengemukakan pendapat karena takut dan malu ditertawakan temanya jika salah terkait lompat jauh gaya jongkok, (5) kurangnya pemahaman peserta didik terhadap model pembelajaran kooperatif tipe NHT, (6) peserta didik kurang bersemangat dan besungguh-sungguh dalam melakukan lompat jauh gaya jongkok, (7) 
kurangnya kesempatan peserta didik dalam melakukan gerakan lompat jauh gaya jongkok sehingga hasilnya kurang maksimal.

Berdasarkan permasalahan-permasalahan yang dihadapi pada siklus I tersebut maka adapun solusinya yaitu: (1) bagi peserta didik yang kurang mendengarkan saat pemberian materi, peserta didik tersebut akan dipanggil kedepan untuk menjelaskan materi yang sudah diberikan, (2) memberikan penghargaan berupa nilai plus bagi peserta didik yang bersungguh-sungguh pada saat melakukan gerakan lompat jauh gaya jongkok sehingga pandangan dapat mengarah ke depan, (3) memberikan pertanyaan mengenai materi yang sudah disampaikan agar peserta didik tidak ragu-ragu dalam menjawab pertanyaan yang di berikan, (4) mengimplementasi model pembelajaran kooperatif tipe NHT pada peserta didik secara lebih jelas dengan memberikan lembaran tahapan-tahapan pembelajaran kooperatif tipe NHT, (5) memberikan motivasi agar peserta didik menjadi lebih bersemangat dan bersungguhsungguh dalam mengikuti pembelajaran pada siklus II tentang lompat jauh gaya jongkok, (6) membariskan peserta didik 2 bersaf agar peserta didik yang berada di belakang dapat memperhatikan lebih jelas mengenai materi yang disampaikan, (7) membagi peserta didik menjadi jumlah kelompok yang lebih banyak sehingga jumlah peserta didik dalam satu kelompok lebih sedikit sehingga kesempatan dalam melakukan gerakan di setiap peserta didik menjadi lebih banyak.

Pembelajaran pada siklus II berlangsung sangat kondusif, peserta didik sudah mengetahui dan mampu beradaptasi dengan model pembelajaran kooperatif tipe GI. Hal ini terlihat dari aspek aktivitas belajar peserta didik, saat peneliti memperagakan gerakan tidak lagi hanya menonton tetapi aktif bertanya terhadap penjelasan peneliti di setiap tahap gerakan yang diperagakan oleh peneliti. Rata-rata aktivitas belajar lompat jauh gaya jongkoksecara klasikal tergolong aktif. Sedangakan untuk penguasaan materi lompat jauh gaya jongkokberada dalam kategori baik. Peningkatan ini tidak terlepas dari implementasi model pembelajaran kooperatif tipe NHT secara optimal dengan perbaikan-perbaikan pembelajaran sesuai dengan kekurangan-kekurangan yang terjadi pada siklus sebelumnya.

Berdasarkan uraian diatas, ini berarti tingkat ketuntasan hasil belajar lompat jauh gaya jongkok pada siklus II sudah memenuhi standar ketuntasan secara klasikal yaitu sebesar 78 sesuai dengan KKM di SMK Negeri 2 Singaraja. Peningkatan aktivitas dan hasil belajar pada siklus II tersebut dikarenakan: 1) penggunaan model pembelajaran kooperatif tipe NHT dengan pembelajaran berkelompok sudah dipahami oleh peserta didik dan 2) peneliti melakukan perbaikan berdasarkan kendala-kendala yang dialami pada siklus I.

Meskipun pelaksanaan siklus II dinyatakan berhasil, tetapi masih terdapat kendala-kendala yang dihadapi saat penerapan model pembelajaran kooperatif tipe NHT, yaitu: terbatasnya waktu pelaksanaan penelitian sehingga peserta didik kekurangan waktu untuk lebih memahami tahapan-tahapan model pembelajaran yang peneliti terapkan. Dengan adanya kendala tersebut solusi yang peneliti sarankan kepada guru yaitu untuk selanjutnya agar lebih sering menerapkan model pembelajaran kooperatif tipe NHT dalam pembelajaran PJOK, sehingga peserta didik akan semakin paham dengan struktur pembelajaran dalam model pembelajaran kooperatif tipe NHT.

Dari sekian banyak model pembelajaran kooperatif yang ada, salah satunya adalah model pembelajaran kooperatif tipe NHT. Dimana dengan melihat aktivitas dan hasil belajar lompat jauh gaya jongkok ditemukan hasil bahwa dengan mengimplementasikan model pembelajaran kooperatif tipe NHT aktivitas dan hasil belajar peserta didik meningkat dalam materi lompat jauh gaya jongkok. (Trianto, 2007:62).

Berdasarkan penelitian yang sudah dilakukan, adapun keterbatasan dalam melakukan penelitian ini yaitu: keterbatasan waktu pelaksanaan penelitian yang dilakukan 2 siklus, agar tidak mengganggu dari kurikulum sekolah yang sudah dibuat. Berdasarkan hasil penelitian yang telah peneliti lakukan serta teori-teori pendukung hasil penelitian yang telah dipaparkan di atas dapat disimpulkan bahwa penerapan model pembelajaran kooperatif tipe NHT dapat meningkatkan aktivitas dan hasil belajar lompat jauh gaya jongkok pada peserta didik kelas X Boga A3 SMK Negeri 2 SingarajaTahun Pelajaran 2017/2018.

Penelitian yang sudah dilaksanakan ini tidaklah selalu berjalan dengan lancar sesuai dengan yang diharapkan dan yang sudah direncanakan. Karena ada kendala-kendala yang dihadapi peneliti dalam menjalankan penelitian ini. Adapun kendala-kendala yang dihadapi adalah: (a) jumlah alat-alat pendukung yang kurang dari jumlah kelompok belajar yang sudah direncanakan, (b) respon peserta didik untuk memahami materi lambat sehingga harus dijelaskan berulang-ulang.

Dari kendala-kendala yang dihadapi tersebut adapun yang dilakukan peneliti untuk memecahkannya sehingga penelitian yang dilakukan dapat berjalan dengan lancar diantaranya adalah: (a) menggunakan lapangan Bhuana Patra yang sudah ada dan alat yang dimiliki oleh peserta didik, (b) menggunakan kerdus yang sudah ada dan untuk kekurangan Bak Lompat, dan (c) menjelaskan kembali secara berulang-ulang materi yang belum dimengerti.. 


\section{KESIMPULAN DAN SARAN}

Berdasarkan hasil analisis data dan pembahasan di atas dapat ditarik simpulan sebagai berikut. 1) Aktivitas belajar lompat jauh gaya jongkok meningkat melalui implementasi model pembelajaran kooperatif tipe NHT pada siswa kelas X Boga A3 SMK Negeri Singaraja tahun pelajaran 2017/2018, 2) Hasil belajar lompat jauh gaya jongkok meningkat melalui implementasi model pembelajaran kooperatif tipe NHT pada siswa kelas X Boga A3 SMK Negeri 2 Singaraja tahun pelajaran 2017/2018.

Berdasarkan simpulan di atas, dapat dikemukakan saran-saran sebagai berikut. 1) Guru PJOK hendaknya mengimplementasi model pembelajaran kooperatif tipe NHT sebagai salah satu alternatif pembelajaran karena terbukti dapat meningkatkan aktivitas dan hasil belajar lompat jauh gaya jongkok pada pesera didik, 2) Bagi sekolah dapat dijadikan sebagai pedoman dalam pembelajaran PJOK khususnya pada materi lompat jauh gaya jongkok guna meningkatkan aktivitas dan hasil belajar, 3) Diharapkan kepada peserta didik yang dijadikan subjek penelitian selanjutnya lebih memperhatikan dan memahami pembelajaran yang diberikan agar dapat menambah wawasan pengetahuan khususunya dalam pembelajaran materi lompat jauh gaya jongkok maupun pada pembelajaran yang lain, 4) Guru atau peneliti lain diharapkan melakukan penelitian tindakan lanjutan dengan mengimplementasikan pendekatan saintifik dan model pembelajaran kooperatif tipe NHT pada kompetensi dasar yang lain, untuk mengetahui bahwa model pembelajaran ini tidak hanya dapat diterapkan pada pembelajaran atletik, khususnya lompat jauh gaya jongkok.

\section{DAFTAR PUSTAKA}

Dimiyati dan Mudjiono. 2006. Belajar dan Pembelajaran. Jakarta:Rineka Cipta.

Hamalik. 2008. Proses Belajar Mengajar. Jakarta:Bumi Aksara.

Kanca, I Nyoman. 2010. Metodologi Penelitian Keolahragaan. Singaraja : Universitas Pendidikan Ganesha.

Nurhadi. 2004. Pembelajaran Kontekstual dan Penerapannya dalam KBK. Malang: Universitas Negeri Malang.

Nurkancana dan Sunartana. 1990. Evaluasi Hasil Belajar. Surabaya: Usaha Nasional.

Permendikbud no 65. 2013. Tentang Standar Isi Pendidikan Dasar dan Menengah. Jakarta: Kemendikbud

Sudjana. 2004. Penilaian Hasil Proses Belajar Mengajar. Bandung: Remaja Rosdakarya.

Sugiyanto. 1998. Perkembangan dan Belajar Motorik. Jakarta:Departemen Pendidikan dan Kebudayaan.

Trianto. 2007. Model-Model Pembelajaran Inovatif. Jakarta: Prestasi Pustaka Publisher.

Undiksha. 2013. Pedoman Penulisan Skripsi dan Tugas Akhir. Singaraja : Departemen Pendidikan Nasional Universitas Pendidikan Ganesha. 